\title{
Combating the Crime of Money Laundering in Light of Banking Secrecy Acts and Their Impact on Legal Liability , A Comparative Study
}

\author{
Professor : Ali Jabbar Salih - Dean of the Faculty of Law. \\ Jadara University - Jordan
}

\begin{abstract}
One of the most serious contemporary challenges that appear as a result of mmodern technology is money laundering which is practiced through banking operations governed by banking secrecy Acts. This research aims to determine the scope of legal exceptions to combat money laundering that allow banks to disclose and provide public authorities with information and data in specific cases attaining interest of the state and society.These exceptions do not diminish the importance of bank secrecy, but they identify common interests in accordance with the interests of banks, clients and the public interest.This research has reached some results, the most important of which is that bank secrecy is compatible with combating the crime of money laundering and the secrecy of banking if we consider that the basis is the secrecy of banking and exception is the withdrawal of this secrecy.
\end{abstract}

Keywords: Combating money laundering, bank secrecy, legal liability, Jordanian legislation, obligation to disclose information, comparative legislation.

DOI: $10.7176 / \mathrm{JLPG} / 91-03$

Publication date: November $30^{\text {th }} 2019$

\section{Introduction}

Banking has an important role in economic life for its effective role in providing financial services to all categorizes of society such as credit distribution, transfers, opening credits and organizing accounts for clients, in addition to providing loans, project finance, and assisting clients with services related to trade and investment as it plays as a broker of credit distribution. Therefore, banks retain important information related to its clients through reviewing their accounts and providing credits and other services. The collected information becomes related to various aspects of life and represents a fundamental pillar in economic, social, cultural and political activity, it assists the bank in making decisions in almost all areas, and increases their knowledge of their clients, thus banks have become an important information center.

On the other hand, banking is considered a professional work that is obliged to disclose information in special cases in legal conditions in response to technical and legal developments in their field of specialization, as they represent a great role as a source of information in the modern era.

Banks are also obliged by law to protect the financial secrets of clients because they contribute to the strengthening of credit to banks, noting that the intensity in bank secrecy has many disadvantages compared to its limited advantages. The main disadvantage of bank secrecy is covering up money laundering crimes that negatively affect society as a whole and not a limited group.

Therefore, we have to find solutions to this problem which has been spread locally and globally, this will only happen by achieving the optimal bank disclosure to combat money laundering crime through specific legal provisions that mitigate the principle of bank secrecy in exceptional cases to protect the public interests of the community and detect illegal activities.

This research will discuss this issue in three sections. The first section discusses the definition of banking secrecy and the problem of reconciling banking secrecy with anti-money laundering.

The second section will discuss the scope of the Jordanian legislations' compliance with the disclosure of banking secrecy to combat money laundering. The third section discusses the effects of the adherence to disclosure rather than banking secrecy, and legal liability for violating it.

\section{Section One :-the definition of banking secrecy and the problem of reconciliation between banking secrecy and anti-money laundering. \\ Banking secrecy is one of the basics of the work of banks that aims to maintain the secrets of their clients and banking operations within the limits of the provisions of the law, but it may be confused with the limits of bank secrecy before disclosure in certain cases which were drawn by the law with high accuracy for the public interest. A secret is defined as everything that must be considered a secret, not to be known or common for all and not to be disclosed to third party ${ }^{(1)}$.}

${ }^{1}$ Awad,A,G.(1969) Banking Operations from a Legal Point of View, Dar Al-Nahda Al-Arabiya, Cairo, p.727 
Banking secrecy is also defined as "the obligation of banks to protect financial, economic and personal issues relating to clients and other persons that have become familiar with them, while exercising their profession or in the course of this practice, considering that there is a presumption of secrecy of the interest of these clients"(1).

It can be said that the banks are prohibited to disclose the secrets of the clients to a third party, which is considered a negative adherence because they are prohibited to disclose a trustworthy banking operation related to their client while exercising their professional banking activities as it is their duty to refrain giving any information related to its client, provided that the required information has been obtained by the bank during the banking operations.

But the question may arise in this regard is : How to reconcile the fight against money laundering with banking secrecy laws in force in banks?

To answer this important question, it must be noted that what is happening in this area is that there is an exploitation of bank secrecy and a collusion from bank employees to launder money derived from illicit trafficking or from any activity carried out by a person to make illegally obtained funds appears clean by investing them in legitimate purposes because they are considered a weapon in the hands of the owners who can participate by virtue of their influence in the decision-making positions in determining many political and economic trends locally and globally.

When reviewing some legislation, we find that countries vary in the systems of banking secrecy ,Some countries adopt a system of "absolute confidentiality of bank accounts" such as Switzerland ${ }^{(2)}$,Luxembourg and Lebanon $^{(3)}$,while other countries have relaxed this principle by allowing banks to disclose bank information about clients, their accounts and transactions under specific legal conditions such as US legislation.

France is less strict than the rest of its neighbors ${ }^{(4)}$, it has not made a special law dealing with bank secrecy as in Switzerland. However, the French criminal law protects this banking secrecy, which is considered a discreet basis for banking, to the extent that all banks adhere to it to protect their personal interests, where maintaining the banking profession was more effective than the legal provisions, The bank secrecy in France was not forbidden for the judiciary, financial departments and public administrations, which were entitled to be informed of the overall operations with the bank.

Accordingly, international solutions have been introduced regarding the problem of reconciling money laundering with bank secrecy rules. Most of the comparative legislations, including the Jordanian legislation, have adopted the principle of the obligation to disclose money laundering operations to varying standards in addition to penal protection. It also obliged its banks to protect the secrets of their clients to preserve their personal freedom with the identification of some exceptions in relation to the disclosure of suspicious transactions and money laundering which has had a positive impact on the national economy.

Although the application of this principle was to varying degrees, countries have differed in the way they impose their legal protection, some countries were content with the legal protection of bank secrecy stated in the general text of the Penal Code, while other countries resorted to a separate law, it strengthened this obligation and imposed more severe penalties than those stipulated in the Penal Code in to provide greater guarantees for this duty.

It can be noted that, if the law imposes an obligation on banks to preserve the secrets of their clients and this is not an absolute rule but a relative rule subject to some exceptions, some jurisprudence and most comparative legislation also provided for specific cases in which the bank is exempted from this obligation for the interests that worth more protection than the interest for which it was concealed .

The most important of these cases is the obligation to disclose and report financially on the crime of money laundering, that is why countries have permitted a balance between anti-money laundering and bank secrecy. In this way banks will not become a safe place for illicit funds. On the other hand, banks must also commit to disclosing information and reporting suspicious accounts.

Section Two: The scope of compliance of Jordanian legislations and comparative legislations to the disclosure of bank secrecy of Anti- money laundering.

The development of the movement of money transactions around the world in the modern era and the increasing opportunities to invest money in different financial markets away from the traditional restrictions led to the increase of easy opportunities to commit the crime of money laundering, especially in light of the restrictions made against bank secrecy and the exploitation of this principle for personal gain in illegal ways.

Therefore, an international, regional and local effort has been made to establish several agreements and laws that combat such crimes by disclosing bank secrecy.

\footnotetext{
${ }^{1}$ Mghabgab,N.(1986) Smuggling of Money and Bank Secrecy before the Criminal Court, Lebanon, Maoushi and Zakaria Press, p. 20.

${ }^{2}$ Article 37 of the US federal law dated 17/11/1943".

${ }^{3}$ Article 579 of the Law of September 3, 1956 of the Lebanese Penal Code punishes the disclosure of secrets

${ }^{4}$ Nassif, E.(2001) Money Laundering and Bank Secrecy, Legal Framework, Al-Ghazal Publishing, Beirut, p. 80.
} 
Some recent legislation allows the banks to disclose banking information about the clients, their accounts and transactions in certain circumstances or when certain legal conditions are met and for achieving interest of the public ,the society and the national economy such as the legislation in the United States of America, where bank secrecy is a contractual obligation between the bank and the client in accordance with the general rules.

Accordingly, the Bank shall not disclose any data or information about the Client's account or financial transactions to third parties without the client's consent whether explicitly or implicitly.

However, the law permits disclosure of the confidentiality of clients in exceptional cases relating to the public interest, the interest of the bank, in the event of a dispute between the bank and the client and other cases stipulated by the various laws.

In Fact, banks have multiple and complex mechanisms that facilitate the laundering of money because of the secrecy in its work, which is derived from the laws relating to banking secrecy, this fact is incompatible with the efforts made by the State regulatory authorities because the principle of bank secrecy prohibits the bank or banking institution and its employees from disclosing any information or data relating to clients, which the employee has accessed to in virtue of his work.

This principle does not permit any person to access to the client's account even if he is an employee of the bank except for the owner of the account exclusively or his heirs and statutory bodies in exclusive cases ,no telephone information about any account may be given even if the caller claims to be the account holder.

Because of this principle, banks have also reached the stage of not using transparent mailing envelopes to preserve this confidentiality.

As a result, comparative legal systems have unanimously adopted this principle and also adopted a set of sanctions for violators of this principle.

\section{The obligation of Swiss legislation to disclose bank secrecy:}

Switzerland is considered one of the most strict countries in banking secrecy, making Switzerland a global banking center for the collection of capital, especially after the adoption of the codified system of digital secret accounts called (Form B),where the account is dealt with on a digital basis without knowing the name of the account holder, except by the bank manager who personally opens the account and give him a certain number while keeping the name of the owner of the secret.

However, the US pressure on Switzerland to prosecute drug money and various economic crimes forced Switzerland to suspend the use of Digital Secret Accounts (Form B).Therefore, a law on money laundering was recently issued in Switzerland, which came into force on 1 April 1978.

This law obliges banks to disclose and report suspicious accounts to the state and freeze suspicious assets.

Thus, Switzerland has lifted bank secrecy of money laundering, and adopted more disclosure transparency in these actions to reduce the strict confidentiality, in addition to comply with the request of many different parties to reduce the degree of bank secrecy and the criticism of other parties to the intensity of banks secrecy ${ }^{(1)}$.

\section{2 - the obligation of US legislation to disclose bank secrecy.}

The US Congress issued the Currency and Foreign Transactions Reporting Act, the Bank Secrecy Act (BSA) in 1970 to prevent financial institutions from being used as tools by criminals to hide or launder their ill-gotten gains. This law grants the US government the right to monitor the movement of funds and requires banks and other financial institution to provide documentation such as currency transaction reports to regulators and Tax Authority.

In addition to the obligation to keep some documents and records that reveal through investigations tax violations and reporting on the illegal sources of funds.

It is noted that, despite the adoption of the system of confidentiality of bank accounts in the US law, but it is not absolute, banks are allowed to disclose the confidentiality of bank accounts of its clients in exceptional cases involving the public interest, the interest of the bank, in the event of a dispute between the bank and the clients or with the express or implied consent of the client.

The reasons for the disclosure of banking secrecy due to the commitment of banks to the monetary and credit policy adopted by the state, which is the greatest guarantee to maintain the strength of the economy.

The US authorities obtain information and data about client accounts by prosecuting tax evaders or combating dirty money laundering through banks.

In addition to the 1983 treaty between the United States and Switzerland to prosecute illegal actions, Switzerland allowed the disclosure of client accounts in criminal cases related to cases of organized crime in the United States by requesting data or information about customers from the Swiss authorities. The banks are obliged to submit their information to a tripartite committee to be determined by the Federation of Swiss Banks

\footnotetext{
${ }^{1}$ Rabah, Gh.(2005) The Crime of Money Laundering, A Comparative Study of the Modern Book Foundation, Tripoli, Lebanon, p. 599.
} 
(1)

After the attacks of September 11, 2001, the United States of America issued a number of legislation, the most important of which was (The USA Patriot Act) it is intended to facilitate the prevention, detection and prosecution of international money laundering and the financing of terrorism which was signed by the US President on October 26, 2001 after its approval by Congress ${ }^{(2)}$.

\section{The obligation of the Jordanian law to disclose bank secrecy:}

The Jordanian Banking Law No. 28 of $2000^{(3)}$ Includes a set of relevant texts, as in Article (72) which stated that " A bank shall observe full confidentiality regarding all accounts, deposits, trusts, and safe-deposit boxes of its customers. It shall be prohibited from providing directly or indirectly any information thereon except upon a written consent of the owner of such account, deposit, trust or the safe deposit box, or an heir of his, upon a decision issued by a competent judicial authority in a current litigation, or due to one of the permissible situations pursuant to the provisions of this law. This prohibition shall remain in effect even if the relationship between the bank and the client has terminated for any reason whatsoever."

Article (73) of the same law stipulated that : "All present and former administrators of the bank shall be prohibited from providing any information or data on the clients or their accounts, deposits, trusts, safe-deposit boxes, or any of their transactions, or disclosing or enabling others to have access to such information and data in situations other than those permitted under this law. Such prohibition shall apply to anyone who by virtue of his profession, position or work, directly or indirectly, may have access to such information and data, including employees of the Central Bank and auditors."

The Jordanian legislator also stipulates in article (75) of this law the sanctions imposed on those who violate the provisions of articles (72) and (73).

According to the provisions of Article (74) of the Jordanian Banking Law Some people are permitted to access to the information under the bank secrecy,

Article (93 / A) of the same law allowed the bank to notify the Central Bank of any banking transaction or the receipt or payment of funds that is related to or could be related to any crime or illegitimate act.

However, the Jordanian legislator provided for certain cases in which bank secrecy increases with explicit provisions, including the disclosure of suspicious transactions and money laundering operations in order to provide confidence in the banking system.It is to inform the auditor of bank secrecy according to the text of article (32 / a) of the Jordanian Banking Law ${ }^{(4)}$,the auditor shall send his reports to the Central Bank.

Pursuant to the provisions of Article (70) of the Jordanian Banking Law ${ }^{(5)}$, as well as Article (74/a) of the Jordanian Banking Law, the auditors are exempted from the prohibition on confidentiality of bank accounts, in order to perform the duties entrusted to them by law. Or the Central Bank in accordance with the provisions of the Banking Law ${ }^{(6)}$, and then the law authorized the auditors to review the transactions of customers ${ }^{(7)}$.

Article (74 / e) of the Central Bank Law also allows the disclosure of all or some of the data related to the client's transactions necessary to prove the bank's right in a judicial dispute between it and its client. The law also added a state of obligation to report crimes as an exception to bank secrecy.

Article (93) of the Banking Law stipulates that : "If a bank learns that the execution of any banking transaction or the receipt or payment of funds is related to or could be related to any crime or illegitimate act, the bank shall immediately notify the Central Bank accordingly. And if the Central Bank received a notice pursuant to paragraph (A) of this Article, or upon knowledge from another source that the bank has been asked to execute a banking transaction or to receive or pay funds related or could be related to a crime or an illegitimate act, the Central Bank shall issue an order to such bank to refrain from executing the transaction or receiving or paying the funds for a period not exceeding thirty days. In the meantime, the Central Bank shall notify any official or judicial authority of the matter. It also stipulates that, the disclosure of information by a bank under the provisions of this Article shall not be regarded as a breach of the obligation to maintain banking confidentiality. Such bank or the Central Bank shall bear no consequent liability.

There is also a role for the Central Bank and comes after receiving the notice that there are financial transactions with the Commercial Bank that could be related to a crime or an unlawful act. Articles (7) and (8) of the Jordanian Anti- Money Laundering Law No. (46) of 2007 are based on the text of Article (93) of the Banking Law that banks may be liable for receiving or accepting funds which, upon receipt, are known to have been derived from, acquired or used in any way by a criminal act. If the rule is the commitment of banks to maintain

\footnotetext{
${ }^{1}$ Rabah, Gh,Op cit., P. 601.

${ }^{2}$ International Guidelines and Arab Measures and Efforts to Combat Money Laundering, Arab Monetary Fund, Abu Dhabi, 2002.

3 Jordanian Banking Law No. 28 and its amendments of 2000

${ }^{4}$ Article (32) of the Jordanian Banking Law No. 28 of 2000 and its amendments

${ }^{5}$ Article $(70$ / a / b) of the Jordanian Banking Law No. 28 of 2000 and its amendments.

${ }^{6}$ Sa'afin,H, "Internal Audit Organization in Banks and Institutional Governance", Journal of Banks, published by the Association of Banks in Jordan, Issue 7, Volume 28, August 2009, p.67.

7. Awad, A,G.op.Cit p 1099
} 
confidentiality in their relationship with customers ${ }^{(1)}$. An exception to this is that if banks suspect that the client's money was derived from criminal activity, they should be required to immediately report their doubts to the relevant authorities, which is an exception to the principle of bank secrecy ${ }^{(2)}$.

Therefore, the disclosure of the banking secrecy of clients raises the bank's contractual and default responsibility except for the existence of a court or arbitral award to disclose bank transactions of the bank's clients .

In this case, the Bank shall be exempted from default or contractual liability in the event of disclosure of bank secrecy and informing the authorities of the client's accounts and all financial information available to the bank ${ }^{(3)}$.

We can say that the Jordanian law permitted to bypass banking secrecy in order to achieve the public interest and to disclose the operations of money laundering and suspicious money, and thus we notice the commitment of the Jordanian law to the limits of disclosure set by the law.

Section Three: the effects of the obligation of disclosure on bank secrecy and legal liability for violating it. There is no doubt that money laundering has consequences on all aspects of life affected by money laundering.Banking secrecy laws in most countries have led to a variety of positive aspects and they have had a tangible effect in the fight against money laundering, and there is a legal liability for non-compliance with the disclosure of bank secrecy in anti- money laundering.

1. The effects of obligation of disclosure on the detection of money laundering in Jordanian laws and the comparative laws:

Banks have an important role in assisting international and local authorities in detecting money laundering crimes and also they have a significant role in providing various banking services, which make them the primary target of money laundering crimes. Their role in the mechanism of money laundering outweighs the importance of international financial markets.

The commitment of banks to disclose solves the problem of disclosure of professional secrets, which was punishable by law in the case of voluntary reporting before the issuance of the Anti-Money Laundering Law. Banks constantly confirmed this law through its banking instructions, which was considered a crime disclosure of the banking secret of the clients.

Therefore, the fight against money laundering requires criminal legal measures and that these measures remain incomplete, ineffective and outside the framework of cooperation of the financial sector in general and the banking sector in particular because of the important role played by the banking sector in passing money laundering operations ${ }^{(4)}$.

The Bank's important role in detecting money laundering starts from the verification of the identity of all clients, especially when providing various types of accounts opening services, providing loans, organizing a safe deposit lease and fund operations in excess of US \$10,000 or equivalent of other currencies and other services that a bank employee believes to be suspicious.

Therefore, bank employees must adhere to the procedures to be followed by banks to avoid involvement in money laundering operations, which are:Know your clients ${ }^{(5)}$,ccompliance with laws, legislations and instructions of central banks.

In addition to not opening fake accounts or accounts for anonymous persons, cooperating with other banks and supervisory bodies and conducting training programs for employees.

In Swiss law, for example, disclosure is voluntary and not compulsory in banks. In the absence of disclosure, the bank closes their account and notifies the competent authorities.

The German Penal Code (art. 621) requires banking and non-banking financial institutions, as well as natural and juridical persons engaged in financial professions such as businessmen, money-changers and others to report suspicious financial transactions to the competent authorities ${ }^{(6)}$.

Pursuant to French Law No.( 90-614 ) of 1990, amended by Law No. (98-546) of 1998 on the Contribution of Financial Institutions to Anti-Money Laundering resulted from the Drug Trade ;The financial and banking institutions, the public treasury, the financial departments of the Postal Corporation, deposit boxes, stock

\footnotetext{
${ }^{1}$ Article (7) of the Jordanian Anti-Money Laundering Law of 2007 and its amendments stipulates.

${ }^{2}$ Moharib, J, "Banks Commitment to Report Suspicious Operations: A Seminar" Central Bank of Kuwait "in cooperation with the Financial Action Group for the Middle East and North Africa and in coordination with the International Monetary Fund and the World Bank entitled" qualifying experts in the field of combating money laundering and terrorist financing in Kuwait December December 2005 , p. 13

${ }^{3}$ Obaid, R.(202) Confidentiality of Bank Accounts in the Light of Decree Law No. 205 of 1990 and the New Prosecution Law, Dar Al-Nahda Al-Arabiya, Cairo, p.133

${ }^{4}$ Hussein,R,Kh.(2004) Money Laundering, Concept, Methods and Economic Impact, Baghdad College of Economic Sciences University Journal, No. 9, Baghdad University College of Economic Sciences.

${ }^{5}$ Morcos,P.(2006) How to reconcile banking secrecy with the requirements of combating money laundering in the framework of cooperation between the public and private sectors, Union of Arab Banks, Beirut, No. 304,pp. 95-97.

${ }^{6}$ Article 621 of the German Penal Code
} 
exchanges, money changers and securities brokerage firms are obliged to inform the Public Prosecution of transactions involving amounts originating from drug trafficking or the activities of criminal organizations (art. 1, 2 of the Act) ${ }^{(1)}$.

Law No. (96-392) of 1996 added "Insurance brokers and reinsurance"

The obligation to report is not limited to persons practicing a regulated profession such as auditors, lawyers, legal advisers, real -estate brokers, notaries, etc.

It also includes people who practice other professions such as jewelers and old objects, and those who buy and sell real estate and advise them.

In addition to all those whose profession enables them to identify the source of the funds on which they conduct or provide advice such as judicial classifiers, notaries and legal accountants. It also includes lawyers if the matter is outside the duty of confidentiality imposed by law to guarantee the right of defense.

It is noted that the obligation to report suspicious financial transactions in French law is limited to cases of money laundering resulting from the drug trade provided for in Article (272) of the Public Health Law wwhich punishes offenses of fetching, producing, manufacturing and exporting narcotic substances.

It also punishes the attempt to commit any of these offenses, or as a result of one of the offenses set forth in article (415) of the Customs Code or the activity of a criminal organization, as well as the obligation to report any remittances in excess of FF 50,000.

The obligation to report does not extend to the public domain covered by the general crime of money laundering provided for in Article (324-1) of the French Penal Code ${ }^{(2)}$ which is considered a flaw in legislation due to the importance of reporting in detecting money laundering resulting from any criminal activity.

As soon as the reporting takes place, the Public Prosecution shall notify a specific department of the Ministry of Economy and Finance, called TRACFIN, which was created by the law of May 9, 1990, consists of a group of qualified State officials in this field .

The duty of this department is to collect all useful information regarding the incident at hand, and to submit it to the Public Prosecution to determine the origin of the amounts and the nature of the operations included in the notification submitted to the Public Prosecution. When sufficient information is available to establish incidents that reveal drug trafficking offenses or the activities of criminal organizations.

This information shall be submitted to the Public Prosecution, as well as to the Customs Administration, to take the necessary measures to implement the text of Article (415) of the Customs Law, as amended by the Law of December 23, $1998^{(3)}$ which shall be punishable by imprisonment of two to ten years, confiscation of the amounts subject to the crime or equivalent amounts, and a fine of between the amounts of the offenses committed, whether the crime is complete or in the attempted stage. Five times this value, for anyone practicing or attempting to engage in banking between France and abroad, whether through fetching, exporting or clearing. If the place of origin is known to have been obtained directly or indirectly from an offense under the Customs Law or by one of the offenses committed in contravention of the provisions concerning substances or narcotic plants.

Such reporting may result in a suspension of the financial operation to be carried out for a period not exceeding 12 hours, upon the decision of TRACFIN.Suspected funds reported may be temporarily withheld by a decision of the President of the Court of First Instance in Paris, or where appropriate, by the investigating judge, to provide TRACFIN staff with an opportunity to investigate the circumstances of the operation and the conformity of the suspicions that have arisen with reality (art. Law No. 9-614 of July 12, 1990, added to Law No. 93-122 of January 29, 1993.

Regarding Jordanian laws, Article (8) of the Jordanian Anti-Money Laundering Law obliges financial institutions to notify the Anti-Money Laundering Unit, an independent unit of a special nature, established at the Central Bank ${ }^{(4)}$.

2. Legal Liability of Banks for noncompliance with disclosure and reporting of suspicious anti-money laundering operations in Jordanian and comparative law:

Many countries have responded to the threat of money laundering and have passed legislation criminalizing money laundering for example England passed the Drug Trafficking Offenses Act in 1986, prior to the 1988 Vienna Convention due to damage it faces from the drug trade. ${ }^{(5)}$

In the United States, an anti-money laundering law was enacted in 1986 and incorporated into Chapter (18) of the Compilation of Federal Criminal Laws and the First Act of 1956 concerning the laundering of dirty money

\footnotetext{
${ }^{1}$ Article 1, 2, of the French Act No. 90-614 of 1990, as amended by Act No. 98-546 of 1998

${ }^{2}$ Article 324-1 of the French Penal Code

${ }^{3}$ Article 415 of the 1998 French Customs Law

${ }^{4}$ Article 8 of the Jordanian Anti-Money Laundering and Financing of Terrorism Law No. 7 of 2007

${ }^{5} \mathrm{CF}$ : Jacqueline RIFFAULT : Le Blanchiment de capitaux illicites, le Blanchiment de capitaux en droit compare, Revue de science criminelle et de droit pénal compare 1999 P 232.
} 
by financial operations. The second law is contained in Chapter 1957 concerning the laundering of dirty money by financial institutions.

In 1994, the law of Money Laundering Suppression was issued to combat money laundering, whereby all institutions, whether banks or others, are obliged to inform FinCEN ${ }^{(1)}$ for any suspicious movement of funds and report on the movement of large amounts and organization of data ${ }^{(2)}$

In Japan, since October 1990, the Ministry of Finance has instructed banks to verify the identity of anyone opening a new account or transferring large amounts. In July 1992, new laws were enacted on money laundering, whereby banks and financial institutions were obliged to provide the Ministry of Finance through competent channels with information on suspected movements under the supervision of officials. At the same period money laundering comes from the drug trade was criminalized and Measures aimed to develop judicial cooperation between States were adopted ${ }^{(3)}$.

On August 1, 1990, Switzerland issued a law requiring banks and their employees to exercise the necessary caution when opening an account for the customer and knowing his name and home country.

The French legislator has criminalized money-laundering resulting from drug trafficking in Article (222-38) of the Penal Code amended by the Law of May 13, 1996.It also criminalizes money laundering resulting from a customs offense Article (415) of the Customs Law or that resulted by prostitution or procuring stipulated in Article (225-6) of the Penal Code.

The French legislator introduced the criminalization of money-laundering in the French Penal Code and Law No. (96-392) of 13 May 1996which was called the Anti-Money Laundering Law on Drugs and International Cooperation in the Seizure and Confiscation of Proceeds of Crime ${ }^{(4)}$. Law No. (90-614) was promulgated on 12 July 1990 and amended by Act No. (98-546 ) of 2 July 1998

Which is related to the contribution of financial institutions in combating money laundering resulting from drug trafficking. ${ }^{(5)}$

Similarly, an anti-money laundering law was issued in Belgium, Romania, Spain and Slovenia. ${ }^{(6)}$

According to the texts of comparative legislation, we can notice that most of the laws of States have included in its laws obligations to disclose suspicious money and money laundering by stipulating laws criminalizing both money laundering operations and the banks that cover up any information related to money laundering. This indicates the obligation of banks to disclose the crime, in addition to their recognition of disclosure as a legal obligation must be respected and applied in the work of banks, and this is the main objective that they seek to reach.

Obligation is a statement that includes an order to get out of a negative situation towards a particular situation or not to take that situation, that is, to carry out a certain positive activity ${ }^{(7)}$.Accordingly, banks and other financial institutions should do a positive action which is disclosing suspicious financial transactions otherwise, its negative attitude to refrain from reporting would constitute a criminal offense with a criminal penalty ${ }^{(8)}$.

Contrary to some legislation that did not consider the violation of this duty a criminal offense, but considered it an administrative offense and subjected to a series of sanctions provided for in the administrative law, as in the US Secrecy Act, in contravention of the English legislator's plan, which considered it a criminal offense. ${ }^{(9)}$

It should be noted that the French legislator provided in Law No. (90-614) of July 1990 that the breach of the obligation to report suspicious financial transactions, which may result in money laundering, is considered as an offense with a criminal penalty (art. 23);however, by Act No. (98-546) of 2 July 1998, it provided for the abolition of criminal penalties, merely disciplinary accountability for such breaches (art. 17) in line with its plan to reduce criminal penalties. Thus, the French legislator became content with disciplinary rather than criminal responsibility.

The criminal penalty legally prescribed for violating the obligation to disclose and report is consistent with the prevailing principle that legal criminalization requires a legal sanction that the Authority intervenes by force to ensure that it occurs, criminalization was therefore inevitably linked to punishment,and the degree of

\footnotetext{
${ }^{1}$ Abbreviation of Financial Crimes Enforcement Network.

${ }^{2}$ Ropert Powis : in L'économie du blanchiment, sous la direction de Perekop, La collection des/ cahiers Finance , éthique, confiance / Paris 1995 P227 Ets, Raffute Op cit P 23

${ }^{3}$ Institute of international Bankers, Galobalsurvey 1993 p 49.

${ }^{4}$ Abu Al-Wafa,I . Abu Al-Wafa,M.(2002) informing banks about suspicious financial transactions between commitment and responsibility in comparative law and Islamic jurisprudence, electronic directory of Arab law, without a publisher, without a year of publication, p. 59.

${ }^{5}$ Relative à la participation des organisme financiers a la lutte contre le Blanchiment des capitaux provenant du Traffic des stupéfiants

${ }^{6} \mathrm{CF}$ : RIFFAULT. Op.CIT P234-236.

${ }^{7}$ Obeid, M,J.(1999) The Crime of Abstinence: A Comparative Study, Culture for Publishing and Distribution, Amman, Jordan, p. 123.

${ }^{8}$ Article (261) of the German Penal Code, Article (15) of the Egyptian Anti-Money Laundering Law, and Article (14) of the Anti-Money Laundering Law of Qatar.

${ }^{9}$ Shams El-Din, A, T.(2003) A Critical Study of the New Anti-Money Laundering Law, Dar Al-Nahda Al-Arabiya, Egypt,p13
} 
punishment also reflects the degree of criminalization where the balance is not equivalent to all the consequences of criminalization in the prospect of the law. ${ }^{(1)}$

The measures that are applied to crime of the bank and other financial institutions of refraining to report suspicious financial transactions are the same as the measures taken against the crimes of refraining in general .

Which take a negative appearance by refraining from performing a legal duty, where the trend prevails towards expanding the circle of material crimes that are not mistaken to include crimes of refraining, including refraining from reporting the crime, preventing a crime against persons, providing assistance to a person in danger and refraining from testifying in favor of an innocent person ${ }^{(2)}$, where these cases combine one idea, which is to break the rule of indifference and impose an obligation to act in accordance with the rule of criminalization.

These cases combine one idea: breaking the rule of indifference and imposing an obligation to act in accordance with the rule established by criminalization Law. ${ }^{(3)}$

It can be said that once the bank refrains from reporting suspicious financial transactions, it is considered an actor of the crime and is entitled to the penalty prescribed without unnecessary error on its part whenever it is able to perform this duty. This is because the Bank is one of the legal persons that modern criminal legislation tends to determine its criminal liability as it has a considerable will represented by natural people and this is essentially considered as a person under the criminal law and entitled to criminal liability, the imposition of financial penalties and precautionary measures, especially in the crimes of the refrain.

It should be noted that the penalty inflicted on a bank that fails to disclose and report suspicious financial transactions do not prevent the punishment of the bank employee who has the duty to report or the execution of an order .

This is an application of the general rules that determine that the penalty imposed on the legal person in the event of its conditions does not prevent the punishment of natural persons who represent his will as actors or partners according to the circumstances and facts of each crime especially when they have the right conditions for accountability for self-error.

This is not a multiplicity of penalties for a single offense because a natural person is asked as a representative of the administration of the legal person who is seen as the legal person himself and he represents his will.

As for his accountability for his mistake when fulfilling the conditions, he is accountable in accordance with the general rules of the Criminal Code.

This is explicitly stipulated in the last paragraph of Article (121.2) of the French Penal Code, which establishes the criminal liability of legal persons in cases provided for by law or regulation. It states that "criminal liability of legal persons shall not exclude the liability of natural persons who are the perpetrators or partners of the same acts.

As for the legal responsibility for breaching the duty to disclose money laundering operations in Jordanian laws, the most important was the text of the 2007 law, which clarified the position of crime in money laundering operations and provided for a criminal penalty according to the legislation in force in the Kingdom or crimes that any legislation in force is considered as a crime of money laundering according to Jordanian considerations.

One of the most important provisions of the law is the provision contained in the body of Article 16, which denies criminal, civil, administrative or disciplinary responsibility for any natural or legal person referred to in Article (13) of the same law when any of them in good faith has a duty to notify any Of the suspicious transactions or provide information or data about them in accordance with the provisions of the law in addition to the provisions of the Jordanian Banking Law in Article (72) and Article (73) on banking secrecy and not disclose the secrets of banking customers except in the cases permitted by law in Article (74) ${ }^{(4)}$, and the Jordanian legislator has set for each violator Penalties in the Jordanian Penal Law No. 16 of 1960, as amended.

\section{Conclusion}

Legislation governing the secrecy of bank accounts shall ensure that such secrecy should be disclosed, and that the activity of bank clients should be disclosed whenever it concerns the protection of a public interest or the interest of the national economy.

The absolute secrecy of bank accounts may sometimes prevent the disclosure of facts that lead to justice in society, as in the case of graft, the interest of society is to expose corruption and hide behind bank secrecy to conceal crimes as the prevention of evil is better than bringing benefits.

Accordingly, banks are obliged to disclose to third parties' facts that are confidential or related to bank

\footnotetext{
${ }^{1}$ Khalifa, A, M. (1959) The General Theory of Criminalization, A Study in Philosophy, Criminal Law, PhD Thesis, Faculty of Law, Cairo Universityp. 22.

${ }^{2}$ Awad,L,A.(1993) Material crimes and criminal responsibility without error, Arab Renaissance House No. 220 p. $221-222$

${ }^{3}$ Bilal, A, A.(1993) Material Crimes and Criminal Responsibility Without Error, Dar Al-Nahda Al-Arabiya, 1993, No. 220

${ }^{4}$ See Article 72, 73 and 74 of the Jordanian Banking Law No. 28 of 2000, as amended.
} 
secrecy if they are required to do so. Legislation has sought to combat money-laundering by including a provision obliging financial institutions to report suspicious financial transactions and not to consider this as a disclosure of bank secrecy which constitutes a criminal offense.

The expansion of bank secrecy in the absence of a special anti-money laundering law would have encouraged the use of banks as money-laundering channels.

Therefore, bank secrecy should not be an impediment to banks and other financial institutions having the duty to disclose and report suspicious financial transactions.

Although the general rules deals with public officials, but the scope of their application extends to each case where the law imposes a certain obligation, because it is permissible to measure in the articles of legalization to achieve the interest of the accused and it does not conflict with the principle of the legitimacy of crimes and penalties, unlike in the articles of criminalization and punishment, Money Laundering Laws.

Hence, some money-laundering laws were not limited to the general rules, but it explicitly stipulated to encourage banks and other financial institutions to cooperate seriously with anti-money laundering efforts and to reassure those who report in good faith. This is what Jordanian legislation and comparative legislation did.

\section{Results}

Through this research, the researcher has reached the most important results which are:

- The crime of money laundering is a continuous and transnational crime that directly affects all societies regardless of gender, race or religion and It is a general problem that must be addressed by all means .

- The banking secrecy laws of customers were an obstacle in achieving the detection and disclosure of money laundering operations.

However, countries have been aware of this obstacle, which has allowed legislators to stipulate legislation that allows in certain cases to report money laundering for the public interest. This is what has already happened.

- All countries have issued legal provisions that provide legal cover for bank employees to report these crimes without being exposed to the liability of revealing the secrets of the client and among them is Jordan.

- The Jordanian laws allowed the detection and reporting of suspicious transactions such as money laundering operations and inform the competent authorities .

The Jordanian legislation imposes various sanctions on those who violate these laws. It also issued many banking and penal legislation to prevent such cases.

We should note that there the Central Bank of Jordan plays a significant role in overseeing and following up the work of banks. It also has a role in the issuances of the necessary instructions regarding anti- money laundering crime.

\section{Recommendations}

The study recommends the following.

1) Achieve the interest of the client and his right to maintain the confidentiality of information related to him, especially his bank accounts and attain the interest of society and the right to achieve social and economic security.

2) Working with all available means to combat money laundering and not utilizing banking secrecy laws to cover criminal activities.

3) Follow the policy of know your clients because it is the basis for all anti-money laundering measures

4) Paying more attention to any change in the pattern of dealing with the bank with continuous auditing of users when making a deposit or transfer of funds.

5) Banks and financial institutions shall prohibit or maintain anonymous accounts, as was the case in Switzerland, and refrain from conducting suspicious transactions, except after informing the competent authorities.

6) Bank employees should be trained in the anti-money laundering culture by educating them on the latest methods and regulations governing money laundering activities.

7) Appropriate programs and procedures must be prepared against money laundering operations to assist in the detection of modern methods and implement a strict control over suspicious operations.

8) Impose strict and deterrent penalties against anyone involved in the crime of money laundering.

9) Spreading the culture of awareness in universities and national centers and introducing them to the risk of money laundering that is illegally obtained

\section{References}

Abu Al-Wafa,I \& Abu Al-Wafa,M.(2002) informing banks about suspicious financial transactions between 
commitment and responsibility in comparative law and Islamic jurisprudence, electronic directory of Arab law, without a publisher, without a year of publication, p. 59.

Awad,L,A.(1993) Material crimes and criminal responsibility without error, Arab Renaissance House No. 220 p. 221-222.

Awad,A,G.(1969) Banking Operations from a Legal Point of View, Dar Al-Nahda Al-Arabiya, Cairo, p.727.

Bilal, A, A.(1993) Material Crimes and Criminal Responsibility Without Error, Dar Al-Nahda Al-Arabiya, 1993, No. 220

Hussein,R,Kh.(2004) Money Laundering, Concept, Methods and Economic Impact, Baghdad College of Economic Sciences University Journal, No. 9, Baghdad University College of Economic Sciences.

Jacqueline RIFFAULT : Le Blanchiment de capitaux illicites, le Blanchiment de capitaux en droit compare, Revue de science criminelle et de droit pénal compare 1999 P 232.

Khalifa, A, M. (1959) The General Theory of Criminalization, A Study in Philosophy, Criminal Law, PhD Thesis, Faculty of Law, Cairo Universityp. 22.

Mghabgab,N.(1986) Smuggling of Money and Bank Secrecy before the Criminal Court, Lebanon, Maoushi and Zakaria Press, p. 20.

Moharib, J, "Banks Commitment to Report Suspicious Operations: A Seminar" Central Bank of Kuwait "in cooperation with the Financial Action Group for the Middle East and North Africa and in coordination with the International Monetary Fund and the World Bank entitled" qualifying experts in the field of combating money laundering and terrorist financing in Kuwait December 2005, p. 13

Morcos,P.(2006) How to reconcile banking secrecy with the requirements of combating money laundering in the framework of cooperation between the public and private sectors, Union of Arab Banks, Beirut, No. 304,pp. 95-97.

Nassif, E.(2001) Money Laundering and Bank Secrecy, Legal Framework, Al-Ghazal Publishing, Beirut, p. 80.

Obaid, R.(2002) Confidentiality of Bank Accounts in the Light of Decree Law No. 205 of 1990 and the New Prosecution Law, Dar Al-Nahda Al-Arabiya, Cairo, p.133.

Obeid, M,J.(1999) The Crime of Abstinence: A Comparative Study, Culture for Publishing and Distribution, Amman, Jordan, p. 123.

Rabah, Gh.(2005) The Crime of Money Laundering, A Comparative Study of the Modern Book Foundation, Tripoli, Lebanon, p. 599.

Relativeà la participation des organisme financiers a la lutte contre le Blanchiment des capitaux provenant du Traffic des stupéfiants.

Ropert Powis : in L'économie du blanchiment, sous la direction de Perekop, La collection des/ cahiers Finance , éthique, confiance / Paris 1995 P227 Ets, Raffute Op cit P23.

Sa'afin,H, "Internal Audit Organization in Banks and Institutional Governance", Journal of Banks, published by the Association of Banks in Jordan, Issue 7, Volume 28, August 2009, p.67.

Shams El-Din, A, T.(2003) A Critical Study of the New Anti-Money Laundering Law, Dar Al-Nahda Al-Arabiya, Egypt,p31

\section{Laws and Guidelines}

French Customs Law,1998

French Penal Code

International Guidelines and Arab Measures and Efforts to Combat Money Laundering, Arab Monetary Fund, Abu Dhabi, 2002.

Institute of international Bankers, Galobalsurvey 1993 p 49

German Penal Code

Jordanian Anti-Money Laundering Law of 2007 and its amendments stipulates.

Jordanian Banking Law and its amendments of 2000. 